\title{
Investigation of Plastic Behavior of Alloyed Steel Deformed during Martensitic Transformation
}

\author{
R. Kandrotaitè-Janutienè $\dot{\mathrm{a}}^{\mathrm{a}, 1}$ and A. Baltušnikas ${ }^{\mathrm{b}, 2}$ \\ a Kaunas University of Technology, Kaunas, Lithuania \\ ${ }^{\mathrm{b}}$ Lithuanian Energy Institute, Kaunas, Lithuania \\ ${ }^{1}$ raskand@ktu.lt \\ ${ }^{2}$ Arunas.Baltusnikas@1ei.lt
}

УДК 539.4

\section{Исследование пластического поведения деформированной легированной стали при мартенситном превращении}

\author{
Р. Кандротайте-Жанутиене

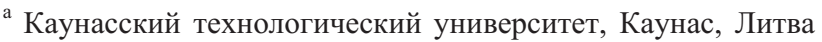 \\ б Литовский энергетический институт, Каунас, Литва
}

Исследованы пластические деформаџии, возникающие в стальных образцах вследствие микроструктурных трансформаций при воздействии внешних нагрузок, уровень которых может не достигать предела текучести материала. Рассматривались три легированные стали - THG200 (производитель Уддехольм, Швеция), $40 X 13$ и $95 X 18$ (Россия) - с разными легирующими элементами и процентным содержанием углерода, а также поведением при микроструктурных трансформациях. При генерировании изгибных напряжений порядка 100 МПа, не превымаюших 10\% предела текучести сталей, наблюдается возникновение пластических зон в стальных образиах, которые подвергались предварительному нагреву до $900 \ldots 1050^{\circ} \mathrm{C}$ и последующему изгибу при закалке на воздухе. Пластические деформации возникали при реализации всех режимов охлаждения, которые сопровождались мартенситным превращением. С помощью рентгенографических исследований было выявлено разное влияние растягивающих и сжимающчих изгибных напряжений на микроструктурнье изменения при мартенситньх превращениях.

Ключевые слова: сталь, микроструктура, пластичность, термообработка, искажение, напряжение.

Introduction. Phase transformations in metals have a major influence on the material behavior in common engineering applications. Steels exhibiting the feature of transformationinduced plasticity (TRIP) reveal the important role of martensite formation during heat treatment processes $[1,2]$.

At temperatures above the martensite start temperature $\left(M_{s}\right)$, austenite-to-martensite transformation can occur when the summation of the mechanical energy due to the externally applied stress exceeds a critical value. This transformation is known as stressassisted nucleation at the same nucleation sites as those responsible for the athermal martensitic transformation that occurs during cooling [3]. An externally stressed specimen in the process of a phase transformation may show a significant nonlinear behavior, which is known as transformation plasticity [4-8]. Even under a small externally applied load stress in relation to the "normal" yield stress of the weakest phase, plastic deformation occurs. The start of martensitic transformation depends highly on the holding stress and its direction: both tension and compression stimulate the process but differently $[9,10]$. 
The austenite-to-martensite transformation and transformation plasticity as well directly depends on the carbon level in the steel and it also depends on the yield strength of the material (initial phase - austenite). The steel with higher carbon content possess more stable retained austenite comparing to the low carbon steel and this can be due to the phenomenon that the transformation of this austenite is not obtained immediately [11].

Most alloying elements that enter into solid solution in austenite at high temperatures lower the martensite start temperature $M_{s}$ during cooling with the exception of cobalt and aluminum [12]. It is also evident that the strong carbide forming elements like chromium, vanadium, titanium and molybdenum have an impact on martensitic transformation start temperature and on transformation plasticity as well $[13,14]$. Thus the different steel grade can exhibit different character of transformation plasticity behavior.

The main aim of the work was to reveal the different influence of compression and tension stresses on the transformation plasticity and phase composition of steel with various chemical compositions during quenching as recent scientific articles do not show a unanimous opinion $[9,15]$. Because of severe service conditions (high temperature, stress, corrosion, irradiation, etc.), alloy steels for the various utility industries must be sufficiently resistant to microstructural degradation. Processes acting inside the steel part during exploitation such as transformation of retained austenite, formation and growth of various carbides can cause the loss of parameters stability, especially when external stresses occur. Therefore, the stability of the microstructure is one of the fundamental requirements concerning the industrial applicability of alloy steels [16]. The microstructural stability of martensitic alloyed steels is achieved by heat treatment consisting of austenitizing, hardening (sometimes to cryogenic temperatures) and high-temperature tempering.

1. Experimental Details. The steel used for the investigation was THG2000 steel (Uddeholm, Sweden) containing chromium, molybdenum and vanadium. The mentioned steel has a wide range of applications in indexable drills, milling cutters and transmission parts for automobiles due to its high resistance to abrasion at both low and high temperatures and resistance to thermal fatigue as well. For the investigation of influence of content of carbon and alloying elements steels 40Kh13 and 95Kh18 (GOST 5632-72) were chosen for experiments for having effective comparison. Chemical composition of steel is presented in Table 1.

$\mathrm{T}$ a $\mathrm{b} 1 \mathrm{e} 1$

Chemical Composition of Steels (\%)

\begin{tabular}{|c|c|c|c|c|c|c|c|c||}
\hline \hline Steel grade & $\mathrm{C}$ & $\mathrm{Si}$ & $\mathrm{Mn}$ & $\mathrm{Cr}$ & $\mathrm{Ni}$ & $\mathrm{Mo}$ & $\mathrm{V}$ & $\mathrm{Fe}$ \\
\hline THG2000 & 0.39 & 1.00 & 0.40 & 5.30 & 0.15 & 1.30 & 0.90 & Bal. \\
\hline 40Kh13 & 0.35 & 0.35 & 0.40 & 13.02 & 0.30 & - & - & Bal. \\
\hline 95Kh18 & 0.97 & 0.60 & 0.59 & 17.64 & 0.39 & 0.10 & - & Bal. \\
\hline
\end{tabular}

The specimens with rectangular cross-section were made with the dimensions $6 \times 8 \times 100 \mathrm{~mm}$ from hot rolled rod $\varnothing 11.2-14.0 \mathrm{~mm}$. The specimens of steel THG were austenized in a protective environment $\left(\mathrm{N}_{2}+\mathrm{CO}+\mathrm{CO}_{2}\right)$ at $900,940,980$, and $1020^{\circ} \mathrm{C}$ for air quenching. The same heating was provided for steels $40 \mathrm{Kh} 13$ and $95 \mathrm{Kh} 18$ just at $1050^{\circ} \mathrm{C}$ temperature. The specimens were hardened choosing the different quenching temperature that allowed getting different solubility of carbides and thus the different composition of the solid solution of steel.

For the investigation of transformation plasticity, the austenized specimen was placed at the special bending device [17] and air cooled. At the set temperature the specimen is loaded in bending load generated bending stress of $100 \mathrm{MPa}$ and not exceeded $15 \%$ of steel 
yield strength $R_{p 0.2}$ at the certain temperature - yield strength of THG2000 is $R_{p 0.2}=$ $=730 \mathrm{MPa}$ at $T=550^{\circ} \mathrm{C}$ [18]. The martensitic start temperature of the steel depends on austenitizing temperature and for steel with the similar chemical composition is $270-370^{\circ} \mathrm{C}$ [19], so, the mentioned temperature $550^{\circ} \mathrm{C}$ was very approximate start of bending and it ensured that the martensitic transformation would start later and the very beginning of bending would be registered. The plastic deflection of specimen was measured in accuracy of $0.01 \mathrm{~mm}$ until the temperature of specimen reached room temperature.

It was also investigated the microstructure of the samples by monitoring with optical microscope Nikon with objective Nikon T.U. Plan Fluor $100 \times / 0.90$ and video camera Nikon DS-R:2 16 MP. Following thermal or thermal-mechanical treatment, the samples for optical analysis were ground, polished, and etched in 3\% Nital solution.

The temperature of specimen during heat treatment was measured by welded chromelalumel thermocouple of $0.3 \mathrm{~mm}$ wire diameter.

The XRD analysis were performed on the D8 Advance diffractometer (Bruker AXS, Karlsruhe, Germany) operating at the tube voltage of $40 \mathrm{kV}$ and tube current of $40 \mathrm{~mA}$. The X-ray beam was filtered with $\mathrm{Ni} 0.02 \mathrm{~mm}$ filter to select the $\mathrm{CuK}_{\alpha}$ wavelength $(\lambda=$ $=1.5406 \AA$ ). . Diffraction patterns were recorded in a Bragg-Brentano geometry using a fast counting detector Bruker LynxEye based on silicon strip technology. The specimens of metal and electrochemically extracted carbides were scanned over the range $2 \theta=25-90^{\circ}$ and $2 \theta=3-100^{\circ}$, respectively, at a scanning speed of $6 \% \mathrm{~min}$ using a coupled two theta/theta scan type.

The XRD analysis allowed identify the type of phases, i.e., content of retained austenite at the compressed and stretched surfaces of specimen.

\section{Results and Discussion.}

2.1. Investigation of Transformation Plasticity of Steel during Air Quenching from Different Austenitizing Temperatures. The annealed microstructure of alloyed steel is composed of a solid solution (mainly ferrite) and different quantities of small disperse carbides of alloyed elements (Fig. 1). Amount of carbides depends on the ratio between carbon and alloying elements. Since steel $95 \mathrm{Kh} 18$ has the biggest content of carbon and alloying elements, thus the carbides are clearly visible and the largest ones (max 7-9 $\mu \mathrm{m}$ ) comparing with microstructure of the other steels (Fig 1c). However, because of influence of vanadium, microstructure of steel THG2000 shows large amount of disperse carbides that look like black areas (Fig. 1a). Increasing austenitizing temperature, more and more carbides dissolves in solid solution enriching it with carbon, chromium and molybdenum. Different chemical composition of austenite will give a response showing multiform plasticity during martensitic transformation. Distantly visible primary grain boundaries can be seen as well.

During air quenching of specimens of steel THG2000 after heating at austenitizing temperature the martensite transformation did not start immediately. Since bending stress is less than yield point of austenite, just elastic deflection of a hot specimen can be determined. Increasing temperature of austenitizing allowed solid solution to become more satiated with alloying elements $(\mathrm{Cr}$, Mo), thus obtaining different $\mathrm{Ms}$ temperature and different value of plasticity occurred during martensitic transformation (Fig. 2). The martensitic transformation started (label 1 in Fig. 2) at about $370^{\circ} \mathrm{C}$ for lower austenitizing temperature $\left(900-940^{\circ} \mathrm{C}\right)$ and finished at approximately $310^{\circ} \mathrm{C}$ for higher heating temperatures $\left(980-1020^{\circ} \mathrm{C}\right)$ as austenite became enriched with carbon and alloying elements after dissolution of small carbides at high temperature. Figure 2 definitely shows that the mechanical strength of steel drops dramatically during martensitic transformation.

The total plastic deflection obtained after martensitic transformation had stopped fully and the specimen cooled down was the biggest for the lowest austenitizing temperature (Fig. 2). 


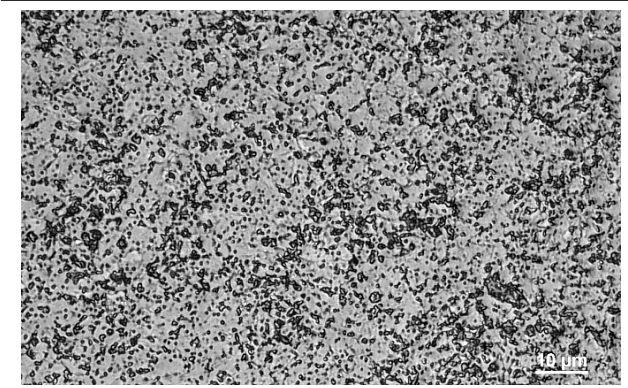

a

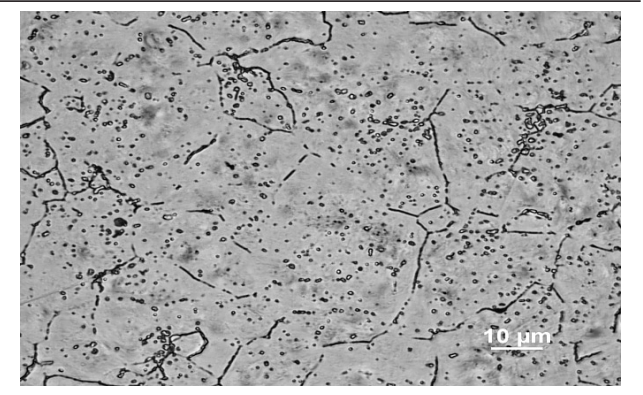

b

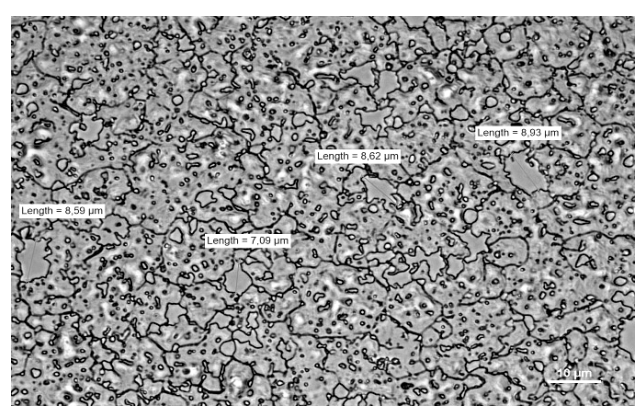

C

Fig. 1. Microstructure of steel THG2000 (a), 40Kh13 (b), and 95Kh18 (c) at annealed state.

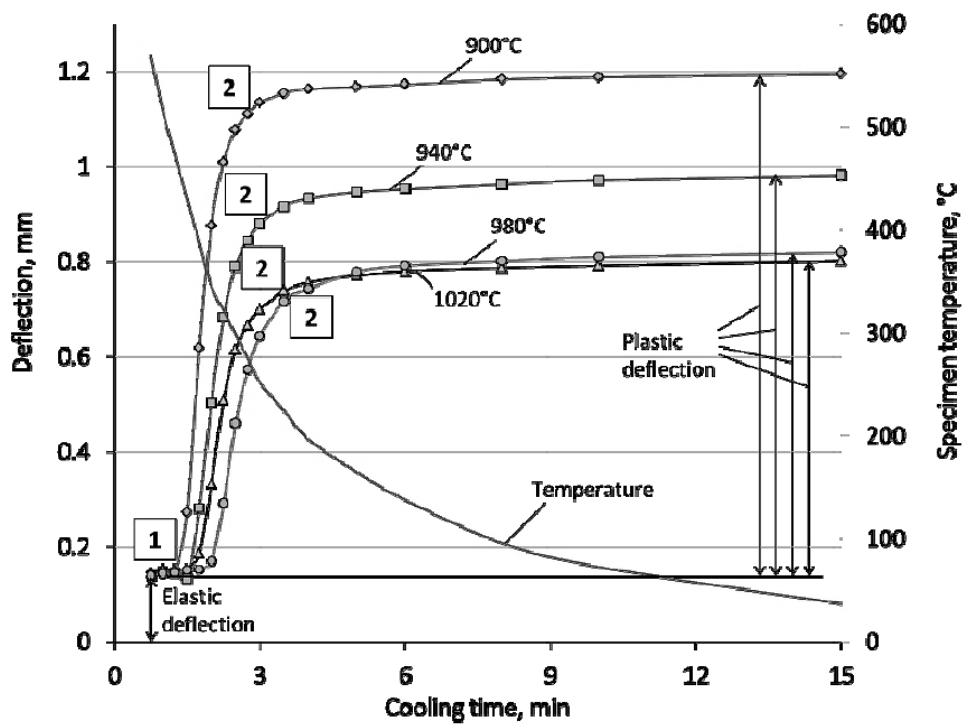

Fig. 2. Plastic behavior of steel THG2000 specimens during air quenching from different austenitizing temperatures. Labels at peaks: 1 - martensitic transformation start; 2 - martensitic transformation finish.

The different amount of total plastic deflection after air quenching from different austenitizing temperatures showed the influence of different alloying degree of steel solid solution. The higher austenitizing temperatures were applied to steel specimens, the less the plastic deflections were obtained. Not only alloying of solid solution had influence on plastic deflection but also the content of retained austenite as increasing the temperature of 
heating raised its amount. Retained austenite remaining from heating till room temperature did not undergo any transformation thus decreased the plasticity of steel specimen during transformation.

Optical analysis of steel THG2000 showed the heterogeneous phase composition of steel composed of laths of martensite, hardly visible small carbides and retained austenite (Fig. 3).

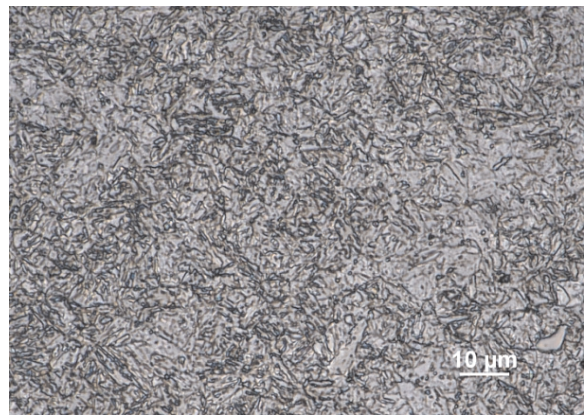

Fig. 3. Microstructure of steel THG2000 at air quenched state. austenitizing temperature $1020^{\circ} \mathrm{C}$.

Content of retained austenite was determined by X-ray analysis recording data from both deformed surfaces of specimen - stretched and compressed (Fig. 4). Analyzing the results of retained austenite obtained after cooling from different temperature it was identified that stretched surface of specimen had less content of retained austenite compared to the compressed one (Fig. 5). This is in a good agreement with other scientific works $[9,10]$ proving that tension stimulates martensitic transformation more than compression.

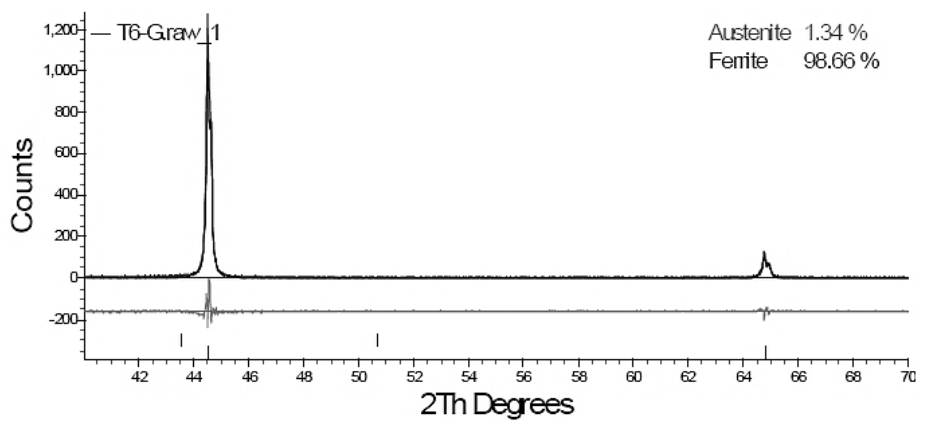

a

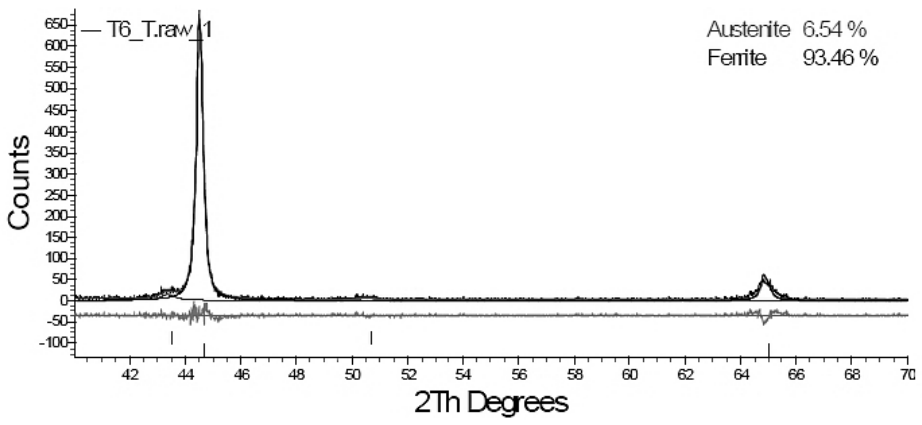

$\mathrm{b}$

Fig. 4. Determination of retained austenite at the surface of steel THG2000 specimen after air quenching from $940^{\circ} \mathrm{C}$ temperature: $\mathrm{a}$ - compressed surface, $\mathrm{b}$ - stretched surface. 


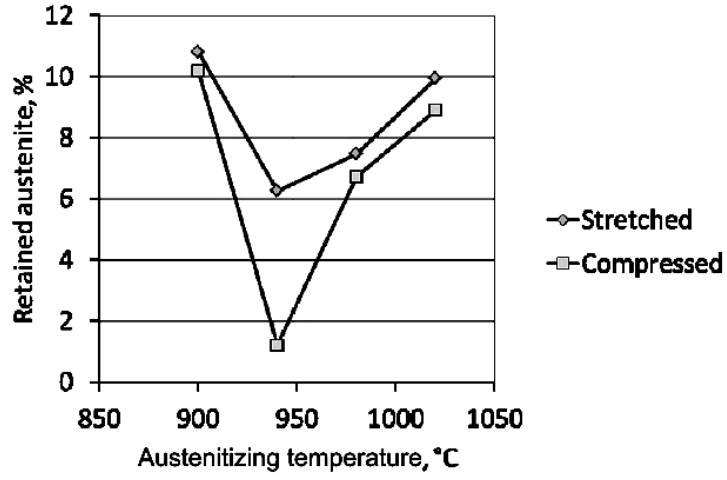

Fig. 5. Content of retained austenite at deformed surface of steel THG2000 specimen after air quenching.

\subsection{Investigation of Chemical Composition Impact on Steel Transformation} Plasticity Occurred during Air Quenching. Less plasticity was obtained for THG2000 steel when compared with steels containing different chemical composition: 40Kh13 and 95Kh18 (GOST) that varied in carbon and chromium content (Fig. 6). This could be explained by the presence of vanadium content in THG2000 steel. As vanadium is strong carbide former (stronger than chromium [14]) the carbides remain stable up to very high heating temperatures almost melting ones. These carbides block plastic deformation during transformation of steel.

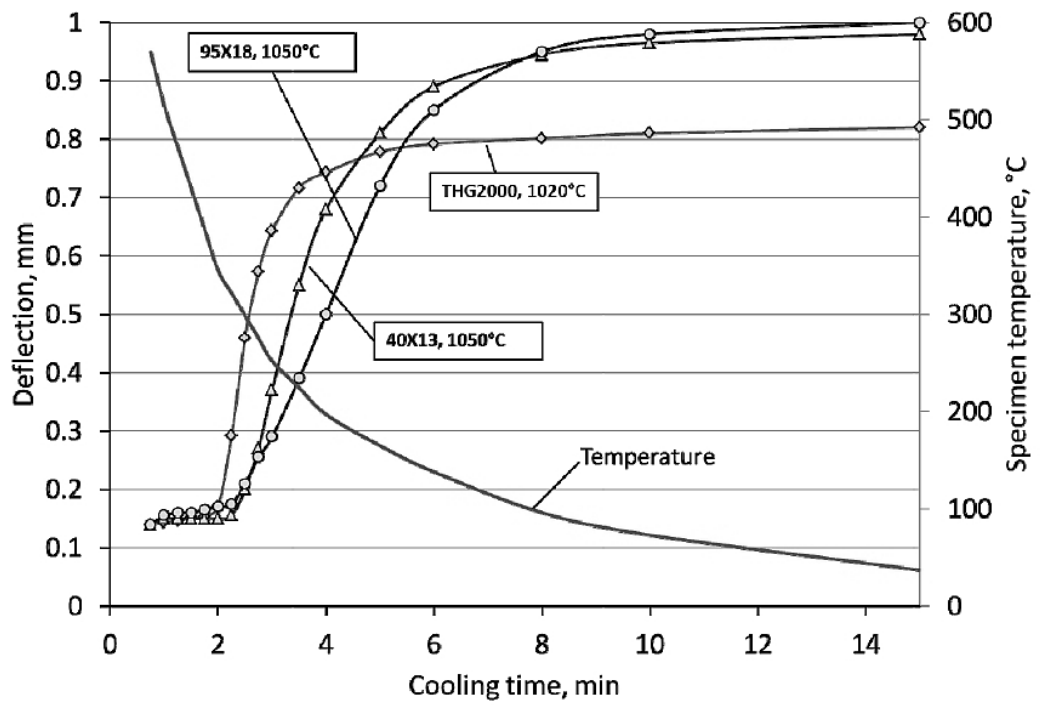

Fig. 6. Influence of chemical composition on plastic behavior of alloyed steel during air quenching.

For better understanding of plastic behavior of steel during martensitic transformation it is necessary to know the phase composition of each steel grade and their critical temperatures. Such data is presented in Table 2.

Further investigations showed [10,13,17], that transformation plasticity is very affected by amount of carbon in steel: the higher content of carbon was, the higher transformation plasticity was obtained. So, the data from Table 2 shows that during heating at austenitizing temperature all steels contained not dissolved carbides. However, the 
difference is that primary carbides such as vanadium-rich $\mathrm{MC}$ carbides, molybdenum-rich M6C carbides and chromium-rich M7C3 carbides remain in steel $\mathrm{THG} 2000$ at $1020^{\circ} \mathrm{C}$ temperature [20], whereas $1050^{\circ} \mathrm{C}$ temperature is sufficiently high for dissolution of the biggest part of carbides in steels $40 \mathrm{Kh} 13$ and $95 \mathrm{Kh} 18$ [14]. That is, solid solution of steel THG2000 at $1020^{\circ} \mathrm{C}$ had less carbon and alloying elements compared to $40 \mathrm{Kh} 13$ and 95Kh18. The steel specimens with smaller plastic deflection (Fig. 6) also contained retained austenite that did not transform during air quenching. As the transformation plasticity is related with transforming of austenite to martensite, less volume of formed martensite presented lower transformation plasticity.

$\mathrm{T}$ a b 1 e 2

Phase Composition and Critical Temperatures of Steel [19-23]

\begin{tabular}{|c|c|c|c|c|c|c||}
\hline $\begin{array}{c}\text { Steel } \\
\text { grade }\end{array}$ & $\begin{array}{c}\text { Austenitizing } \\
\text { temperature } \\
T,{ }^{\circ} \mathrm{C}\end{array}$ & $\begin{array}{c}\text { Phase composition } \\
\text { at austenitizing }\end{array}$ & $\begin{array}{c}A_{c 1}, \\
{ }^{\circ} \mathrm{C}\end{array}$ & $\begin{array}{c}A_{c 3}, \\
{ }^{\circ} \mathrm{C}\end{array}$ & $\begin{array}{c}M_{s}, \\
{ }^{\circ} \mathrm{C}\end{array}$ & $\begin{array}{c}\text { Phase composition } \\
\text { after air quenching } \\
\text { (XRD results and } \\
\text { literature sources) }\end{array}$ \\
\hline THG2000 & 1020 & $\begin{array}{c}\text { Austenite }+ \text { primary } \\
\text { carbides }\end{array}$ & 840 & 870 & $\begin{array}{c}270- \\
300\end{array}$ & $\begin{array}{c}\text { Martensite }+ \\
\sim 8-9 \% \text { retained } \\
\text { austenite + primary } \\
\text { carbides }\end{array}$ \\
\hline $40 \mathrm{Kh} 13$ & 1050 & $\begin{array}{c}\text { Austenite }+ \text { few } \\
\text { carbides }\end{array}$ & 820 & $860-$ & $145-$ & $\begin{array}{c}\text { Martensite }+ \\
270 \\
\text { few carbides }+ \\
\sim 3-4 \% \text { retained } \\
\text { austenite }\end{array}$ \\
\hline $95 \mathrm{Kh} 18$ & 1050 & $\begin{array}{c}\text { Austenite }+ \text { few } \\
\text { carbides }\end{array}$ & 830 & $\begin{array}{c}925- \\
1100\end{array}$ & $\sim 260$ & $\begin{array}{c}\text { Martensite } \\
\text { (with 11\% Cr and } \\
0.25 \% \mathrm{C})+ \\
\sim 10-19 \% \text { retained } \\
\text { austenite }+ \text { few } \\
\text { carbides }\end{array}$ \\
\hline
\end{tabular}

Conclusions. Analyzing the results of experiments and sources of scientific literature, such conclusions were made:

1. Martensitic transformation plasticity occurs in each grade of steel and can be observable as plastic deflection of specimen for all martensitic transformation process. Transformation plasticity of steel THG2000 increased from 25 to $35 \%$ when austenitizing temperature decreased from 1020 to $900^{\circ} \mathrm{C}$. The difference in plasticity is related with dissolution of carbon and alloying elements in solid solution at higher temperatures. Content of retained austenite also had an impact on total plastic deflection of specimen.

2. Chemical composition of steel had influence on transformation plasticity of steel. The steel with solid solution saturated with the biggest content of dissolved carbon and alloying elements presented the highest transformation plasticity. Total plastic deflection of specimens of steels $40 \mathrm{Kh} 13$ and $95 \mathrm{Kh} 18$ overtook the bending of steel THG2000 specimens almost $20 \%$ as this steel contained hard soluble primary carbides of vanadium and molybdenum decreasing the saturation of solid solution with carbon.

3. During bending two types of stresses act. XRD analysis showed that stretched surfaces of specimens contained more retained austenite compared to the compressed ones at all austenitizing temperatures. The difference obtained was approximately $2-4 \%$. Agreeably with the further investigations and data from literature sources the assumption of higher compression stimulation of martensitic transformation can be made. 
Acknowledgments. This work has been performed in collaboration with Lithuanian Institute of Energy.

\section{Резюме}

Досліджено пластичні деформації, що виникають у стальних зразках внаслідок мікроструктурних трансформацій при дії зовнішніх навантажень, рівень яких може не досягати границі плинності матеріалу. Розглядалися три леговані сталі - THG200 (виробник Уддехольм, Швеція), 40X13 та 95X18 (Росія) - 3 різними легованими елементами і процентним вмістом вуглецю та поведінкою при мікроструктурних трансформаціях. При генеруванні згинальних напружень порядку 100 МПа, що не перевищує 10\% границі плинності сталей, має місце виникнення пластичних зон у стальних зразках, які піддавали попередньому нагріванню до $900 \ldots 1050^{\circ} \mathrm{C}$ і наступному згину при загартуванні на повітрі. Пластичні деформації виникали за реалізації всіх режимів охолодження, які супроводжувалися мартенситним перетворенням. За допомогою рентгенографічних досліджень виявлено різний вплив розтяжних і стискальних згинних напружень на мікроструктурні зміни при мартенситних перетвореннях.

1. H. P. Hallberg, M. Hakansson, and A. Ristinmaa, "Constitutive model for the formation of martensite in austenitic steels under large strain plasticity," Int. J. Plasticity, 23, No. 7, 1213-1239 (2007).

2. J. Min, L. G. Hector, Jr., L. Zhang, et al., "Plastic instability at elevated temperatures in a TRIP-assisted steel," Mater. Design, 95, 370-386 (2016).

3. G. Olson and M. Cohen, "Classical and nonclassical mechanisms of martensitic transformations," J. Phys. Colloq., 43 (C4), C4-75-C4-88, (1982).

4. F. D. Fischer, E. R. Oberaigner, K. Tanaka, and F. Nishimura, "Transformation induced plasticity revised an updated formulation," Int. J. Solids Struct., 35, No. 18, 2209-2227 (1998).

5. F. D. Fischer, G. Reisner, E. Werner, et al., "A new view on transformation induced plasticity (TRIP)," Int. J. Plasticity, 16, 723-748 (2000).

6. L. Taleb, N. Cavallo, and F. Waeckel, "Experimental analysis of transformation plasticity," Int. J. Plasticity, 17, 1-20 (2001).

7. N. Tsuchida and Y. Tomota, "A micromechanical modeling for transformation induced plasticity in steels," Mater. Sci. Eng. A, 285, 345-352 (2000).

8. M. Coret, S. Calloch, and A. Combescure, "Experimental study of the phase transformation plasticity of 16MND5 low carbon steel under multiaxial loading," Int. J. Plasticity, 18, 1707-1727 (2002).

9. M. Fischlschweiger, Th. Antretter, and G. Cailletaud, "Transformation hardening and kinetics for stress assisted and temperature driven martensitic transformation in steels," Mech. Res. Commun., 47, 84-88 (2013).

10. R. K. Janutienė and R. K. Dičkuvienè, "External stress effect on microstructure and transformation plasticity of hot work tool steel during quenching," Strength Mater., 47, No. 5, 728-739 (2015).

11. R. Kuziak, R. Kawalla, and S. Waengler, "Advanced high strength steels for automotive industry," Arch. Civ. Mech. Eng., 8, No. 2, 103-118 (2008).

12. K. Hiroyuki and K. Sasaki, "Transformation-induced plasticity as the origin of serrated flow in a NiTi shape memory alloy," Int. J. Plasticity, 50, 37-48 (2013). 
13. R. Kandrotaitè-Janutienè, Investigation of Transformation Plasticity of Tempered Carbon and Chromium Steel [in Lithuanian], Doctoral Dissertation, Technologija, Kaunas (2004).

14. I. I. Novikov, Theory of Heat Treatment of Metals, Mir, Moscow (1978).

15. J. Videau, Ch. Cailletaud, and G. Pineau, "Experimental study of the transformation induced plasticity in a Cr-Ni-Mo-Al-Ti steel," in: Int. Seminar MECAMAT'95: Mechanisms and Mechanics of Solid - Solid Phase Transformations (May 16-19, 1995, La Bresse, France) (1995).

16. J. Janovec, M. Svoboda, and J. Blach, "Evolution of secondary phases during quenching and tempering 12\% Cr steel," Mater. Sci. Eng. A, 249, 184-189 (1998).

17. J. Žvinys and R. Kandrotaitè-Janutienè, "Carbon and tempering temperature influence on steel kinetic plasticity," Mater. Sci. (Medžiagotyra), 6, No. 3, 172-174 (2000).

18. Uddeholm THG2000. http://www.uddeholm.com/files/hotvar-english.pdf [visited 27-01-2016].

19. L. E. Popova and A. A. Popov, Diagrams of Austenite Transformation in Steels and Beta Solution of Titanium Alloy [in Russian], Metallurgiya, Moscow (1965).

20. A. Medvedeva, J. Bergström, S. Gunnarsson, and J. Andersson, "High-temperature properties and microstructural stability of hot-work tool steels," Mater. Sci. Eng. A, 523, 39-46 (2009).

21. V. G. Sorokin (Ed.), Grades of Steels and Alloys [in Russian], Mashinostroenie, Moscow (1989).

22. J. A. Geler, Instrumental Steels [in Russian], Metallurgiya, Moscow (1975).

23. A. P. Shliamnev (Ed.), Stainless, Heat Resistant and High-Strength Steels and Alloys. Handbook [in Russian], Intermet Engineering, Moscow (2000).

Received 25. 04. 2016 